\title{
Peran Perceived Effectiveness of Escrow Services terhadap Satisfaction dan Trust pada E-Commerce di Indonesia
}

\author{
Ratna Dewi Kusumawati ${ }^{\mathrm{a}, *}$, \& Hanif Aulawi ${ }^{\mathrm{b}}$ \\ ${ }^{a}$ Departemen Akuntansi, Universitas Bina Insani \\ ${ }^{b}$ Departemen Manajemen, Universitas Bina Insani
}

\begin{abstract}
The COVID-19 pandemic has compelled consumers to purchase goods/services from their homes through various e-commerce applications. Deepening e-commerce penetration requires improved consumers satisfaction and trust. To do so, e-commerce firms have offered escrow services to safeguard the processing of payment made on the e-commerce platforms. This study analyzes the role of consumer-perceived effectiveness of escrow services on satisfaction and trust by using a nonprobabilistic survey. Further, this study also uses the moderated regression analysis method. We find that consumers' satisfaction of previous purchases significantly affect their trust in the seller, thereby suggesting that perceived effectiveness of escrow services can moderate the relationship between satisfaction and trust variables.
\end{abstract}

Keywords: e-commerce; escrow; satisfaction; trust

\begin{abstract}
Abstrak
Keadaan pandemi COVID-19 mendorong masyarakat untuk berbelanja dari rumah dengan menggunakan e-commerce. Faktor kepuasan dan kepercayaan konsumen merupakan dua faktor kunci dalam meningkatkan penetrasi $e$-commerce. Guna meningkatkan kepercayaan dan kepuasan konsumen, pengelola e-commerce menawarkan jasa escrow dalam memproses pembayaran yang dilakukan pada platform e-commerce. Penelitian yang dilakukan merupakan penelitian kuantitatif non-probability dengan mengumpulkan data melalui kuisioner dan analisis data menggunakan metode moderated regression analysis. Hasil penelitian menunjukkan kepuasan yang dirasakan oleh responden terhadap pembelian sebelumnya dapat mempengaruhi kepercayaan konsumen terhadap penjual. Variabel perceived effectiveness of escrow services mampu memoderasi hubungan antara variabel kepuasan dan kepercayaan.
\end{abstract}

Kata Kunci: e-commerce; escrow; kepuasan; kepercayaan Kode Klasifikasi JEL: B27; D18; D91

${ }^{*}$ Alamat Korespondensi Penulis: Universitas Bina Insani, Jl. Siliwangi No. 6, Rawa Panjang, Kota Bekasi, Indonesia, Telp.: +62-21-82446886. E-mail: ratnadewi@binainsani.ac.id. 


\section{Pendahuluan}

Indonesia menjadi salah satu negara yang sangat menarik bagi para penyedia layanan e-commerce atau pasar daring (Rahayu, 2019). Banyak e-commerce yang ikut masuk untuk memenangkan persaingan di pasar Indonesia. Pada kuartal 4 tahun 2019, jumlah e-commerce yang menawarkan jasa dan ikut bersaing di pasar Indonesia berjumlah 47 e-commerce (iPrice, 2019). E-commerce tersebut memiliki mekanisme yang berbeda-beda, ada yang hanya menjadi perantara antara penjual dan pembeli, dan ada yang menjual barangnya sendiri maupun menjadi perantara.

Tertariknya pengelola e-commerce untuk masuk ke pasar Indonesia salah satunya disebabkan oleh tingginya tingkat penetrasi penggunaan internet di Indonesia. Masyarakat yang menggunakan internet di Indonesia sudah mencapai $64 \%$ dari keseluruhan populasi (Kemp, 2020). Ditinjau dari jumlah penduduk, masyarakat di Indonesia yang menggunakan internet berjumlah 175,4 juta. Masyarakat mengakses internet melalui berbagai perangkat, salah satunya melalui telepon pintar (smart phone). Sebanyak 55\% masyarakat Indonesia yang mengakses internet melalui smartphone menggunakan perangkatnya untuk mengakses aplikasi berbelanja (e-commerce) (Kemp, 2020). Salah satu e-commerce yang sering dikunjungi oleh masyarakat di Indonesia adalah Tokopedia (Kemp, 2020).

Banyak faktor yang mempengaruhi seseorang melakukan pembelian di marketplace, baik melalui website maupun juga aplikasi. Beberapa faktor tersebut diantaranya adalah website design quality (Akbar \& Azeemi, 2017), trust (Sullivan \& Kim, 2018), satisfaction, risks, transaction-based uncertainties (Mou et al., 2017) dan faktor lain. Masih banyak faktor lain yang terbukti memengaruhi seseorang untuk melakukan pembelian di e-commerce, namun satisfaction dan trust menjadi dua variabel yang menarik dan banyak diteliti.

Satisfaction merupakan salah satu faktor yang dapat mempengaruhi seseorang memiliki intensi untuk melakukan pembelian kembali di e-commerce (Elbeltagi \& Agag, 2016; Sharma \& Lijuan, 2015). Satisfaction juga dapat membuat para konsumen di $e$-commerce tetap membeli ditoko yang sama sehingga akan mempertahankan penjualan (Nisar \& Prabhakar, 2017; Ting et al., 2016). Penelitian lain menyebutkan satisfaction merupakan salah satu faktor penting agar para penjual dapat bertahan dan terus melangsungkan bisnisnya (Nisar \& Prabhakar, 2017). Penelitian yang telah dilakukan memberikan penegasan tersendiri bahwa untuk dapat mempertahankan bisnis di e-commerce, para penjual harus bisa menciptakan kepuasan bagi para konsumen agar mereka mau membeli kembali di toko daring dan bisnis dapat terus berjalan.

Faktor yang perlu diperhatikan dalam e-commerce lainnya adalah trust atau kepercayaan. Beberapa penelitian yang telah dilakukan menunjukkan bahwa kepercayaan akan mempengaruhi seseorang untuk melakukan pembelian (Oliveira et al., 2017) dan juga melakukan pembelian kembali (Sullivan \& Kim, 2018). Kepercayaan dalam e-commerce dibutuhkan karena ada risiko dalam transaksi yang dilakukan, salah satunya adalah kehilangan uang yang ditransfer (Nisar \& 
Prabhakar, 2017) dan risiko lainnya.

Ada hal yang perlu diperhatikan dari kedua faktor penting di e-commerce, yaitu bahwa satisfaction merupakan salah satu faktor yang dapat membangun kepercayaan konsumen (Kassim \& Abdullah, 2010). Penelitian terdahulu menyatakan bahwa satisfaction dapat memengaruhi kepercayaan (Oliveira et al., 2017; Lee \& Wong, 2016). Pembeli yang merasa puas pada pembelian yang telah dilakukan cenderung untuk percaya kepada penjual di e-commerce.

Beberapa tahun yang lalu di dunia e-commerce muncul layanan yang bernama layanan escrow. E-commerce besar yang bermain di pasar Indonesia sebagian besar telah menggunakan jasa escrow (Tempo.co, 2017). Jasa escrow berperan untuk menyimpan dana konsumen hingga konsumen mendapatkan barang yang dibelinya dan barang tersebut sesuai dengan kesepakatan (Xu et al., 2015). Jasa escrow pada e-commerce bertujuan untuk melindungi konsumen dari risiko potensial yang muncul pada transaksi online (Fang et al., 2014). Layanan escrow pada e-commerce melepaskan dana kepada penjual apabila pembeli telah menerima barang dan setuju untuk membayar (Fang et al., 2014). Jasa escrow yang dihadirkan di e-commerce Indonesia diharapkan dapat membangun dan menumbuhkan rasa aman bagi konsumen dalam melakukan transaksi di e-commerce dan mendorong terjadinya transaksi (SWA.co.id, 2016).

Pengelola e-commerce memahami bahwa jasa escrow sangat penting bagi usaha yang mereka jalankan. Dengan adanya escrow service pada e-commerce diharapkan tingkat kepercayaan masyarakat dalam transaksi penjualan secara online akan meningkat. Masyarakat tidak perlu ragu dalam membelanjakan uangnya di $e$ commerce. Pengelola e-commerce berbondong-bondong akan melengkapi usaha mereka dengan escrow service. Setiap transaksi yang berhasil pada e-commerce yang telah menggunakan escrow service akan membuat konsumen puas, sehingga tingkat kepercayaan pada e-commerce tersebut akan terus tumbuh dan terjaga.

Satisfaction adalah variabel yang mengukur tingkat rasa kepuasan konsumen terhadap barang maupun jasa yang mereka terima dari penjual (Eid, 2011). Kepuasan dapat timbul dari dua konsep yang berbeda yaitu kepuasan atas transaksi yang spesifik, dan kepuasan akumulasian yang timbul atas beberapa transaksi yang telah terjadi sebelumnya (Kaura et al., 2015). Lebih lanjut lagi, kepuasan atas transaksi yang spesifik didapatkan oleh konsumen berdasarkan pengalaman atas transaksi tertentu yang spesifik (Kaura et al., 2015). Kepuasan akumulatif merupakan kepuasan yang dirasakan oleh konsumen secara terus-menerus dari transaksi awal yang telah dilakukan hingga transaksi terkini (Kaura et al., 2015).

Berbeda dengan kepuasan, para konsumen akan merasakan ketidakpuasan ketika mereka mendapatkan barang maupun jasa yang tidak sesuai dengan apa yang konsumen ekspektasikan sebelumnya (Rust \& Zahorik, 1991). Perilaku konsumen pada transaksi selanjutnya sedikit banyak akan dipengaruhi oleh kepuasan yang dirasakan pada pembelian yang telah terjadi sebelumnya (Anderson \& Srinivasan, 2003). Konsumen yang merasakan kepuasan pada transaksinya dengan penjual akan merasakan juga keinginan atau intensi untuk melakukan pembelian kembali di masa depan dengan penjual yang sama (Ghane 
et al., 2011).

Pembelian yang dilakukan baik melalui interaksi langsung maupun secara daring dipengaruhi oleh trust atau kepercayaan. Trust adalah sebuah rasa percaya yang muncul dan dirasakan oleh konsumen kepada penjual bahwa penjual yang dituju konsumen akan memenuhi transaksi sesuai dengan kesepakatan yang terjadi (Kim et al., 2009). Trust juga dikatakan dapat mengurangi dampak yang timbul dari ketidakpastian yang ada di lingkungan e-commerce (Palvia, 2009). Selain itu, trust juga hanya diperlukan pada saat konsumen menghadapi situasi yang dianggap berisiko, dimana konsumen tersebut mau untuk menerima dan mengambil risiko (Mayer et al., 1995). Sumber lain menyatakan bahwa trust terdiri dari tiga karakteristik, yaitu ability, benevolence, dan juga integrity (Mayer et al., 1995).

Konsumen yang pernah melakukan transaksi, dapat merasakan kepuasan atau ketidakpuasan, tergantung kepada bagaimana transaksi terjadi dan terselesaikan. Kepuasan itu sendiri akan didapatkan oleh konsumen pada saat konsumen merasa puas terhadap produk atau jasa yang diterima (Byambaa \& Chang, 2012), yang sesuai dengan ekspektasi konsumen. Kepuasan yang dirasakan oleh konsumen dapat mengindikasikan bahwa transaksi selanjutnya di masa yang akan datang akan terlaksana dengan sukses karena penjual memiliki integritas dan juga kemampuan untuk memenuhi transaksi tersebut (Fang et al., 2014). Kepercayaan yang terbentuk pada konsumen itu sendiri dipengaruhi oleh beberapa hal dan salah satunya adalah pengalaman pembelian atau transaksi sebelumnya yang telah terjadi (Jones \& Leonard, 2008). Perilaku positif para konsumen terhadap transaksi yang akan datang juga dipengaruhi oleh pengalaman baik yang dirasakan pada transaksi sebelumnya (Pappas et al., 2014). Konsumen yang merasakan kepuasan akan merasa bahwa penjual mampu menciptakan salah satu komponen yang penting dalam kepercayaan, yaitu customer service ethos (Fang et al, 2014). Berdasarkan pemaparan tersebut, dapat dikatakan bahwa kepuasan yang dirasakan oleh konsumen pada pembelian sebelumnya akan memunculkan persepsi bahwa penjual dapat memenuhi transaksi selanjutnya.

H1: Satisfaction berpengaruh terhadap kepercayaan.

Jasa escrow menyediakan jasa pengamanan pada transaksi yang terjadi antara penjual dan pembeli (Hu et al., 2004). Penggunaan jasa escrow ditujukan untuk memberikan pengamanan dan rasa aman dari adanya kejahatan dalam transaksi (Nah \& Davis, 2002), salah satunya adalah penipuan. Jasa escrow dalam mekanismenya akan memastikan bahwa kesepakatan antara penjual dan juga pembeli harus terpenuhi terlebih dahulu, baru kemudian uang pembeli yang ditahan akan ditransfer kepada penjual (Pavlou \& Gefen, 2004). Jasa escrow yang digunakan dalam $e$-commerce akan membuat konsumen merasa aman, namun hal tersebut bergantung kepada persepsi keefektifan jasa escrow yang tersedia di e-commerce tersebut (Pavlou \& Gefen, 2004), atau dapat disebut juga dengan perceived effectiveness of escrow services (PEES).

Salah satu komponen yang membentuk kepercayaan konsumen dalam membeli di e-commerce adalah keamanan (Azam et al., 2012). Keamanan menjadi 
hal yang penting karena dalam transaksi di e-commerce terdapat ketidakpastian (Pavlou et al., 2007), dimana pembeli tidak bisa melihat motif dan perilaku penjual. Pembelian yang dilakukan secara daring di e-commerce tidak dilakukan secara tatap muka sehingga transaksi yang terjadi dilandaskan pada keyakinan konsumen (Kim et al., 2009).

Pengalaman pada transaksi sebelumnya akan menjadi acuan tindakan di masa depan, namun ternyata hanya dalam situasi yang penuh dengan kepastian (Fang et al., 2014). Pada konteks pembelian kembali di $e$-commerce, dalam situasi yang dirasa aman dan penuh dengan kepastian, konsumen akan cenderung untuk secara otomatis memikirkan pengalaman transaksi sebelumnya (Fang et al., 2014), salah satunya adalah kepuasan yang mempengaruhi kepercayaan konsumen. Perasaan aman dalam transaksi di e-commerce dapat tercipta salah satunya ketika konsumen merasa bahwa jasa escrow yang ada sudah berjalan dengan efektif (Pavlou \& Gefen, 2004). Sebaliknya, pada situasi yang penuh dengan ketidakpastian, konsumen akan cenderung untuk mencari informasi-informasi lain dan kurang bergantung pada pengalaman transaksi sebelumnya (Fang et al., 2014), sehingga konsumen juga akan kurang bergantung pada kepuasan yang dirasakan pada transaksi sebelumnya. Berdasarkan paparan tersebut, dapat dikatakan bahwa hubungan antara kepuasan dan kepercayaan dipengaruhi juga oleh PEES. Hubungan tersebut digambarkan pada Gambar 1.

H2: PEES memoderasi hubungan kepuasan terhadap kepercayaan.

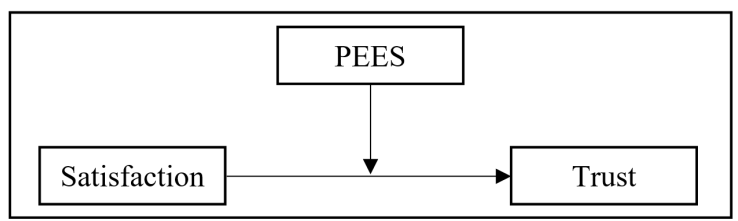

Gambar 1: Hubungan Antar Variabel Penelitian

\section{Metodologi}

Penelitian yang dilakukan merupakan penelitian kuantitatif. Penelitian dilakukan dengan mengumpulkan data melalui kuesioner. Kuesioner dalam penelitian ini didistribusikan melalui Google Form. Penelitian ini menggunakan purposive sampling dalam menentukan sampel. Sampel penelitian ini adalah masyarakat di Indonesia yang sudah pernah melakukan pembelian secara daring melalui e-commerce yang memiliki jasa escrow dalam enam bulan terakhir pada tahun 2019. Responden yang terpilih menjadi sampel adalah responden yang memenuhi kriteria dalam penelitian ini. Responden yang mengisi kuesioner berasal dari berbagai daerah di Indonesia. Jumlah responden yang terlibat berjumlah 
134, akan tetapi jumlah responden yang dapat diproses berjumlah 79. Terdapat sejumlah 55 responden yang tidak mengisi kuesioner secara lengkap.

Penelitian ini menggunakan instrumen yang telah digunakan oleh para peneliti sebelumnya. Instrumen yang digunakan untuk mengukur variabel satisfaction mengadopsi instrumen dalam penelitian Fang yang dilakukan tahun 2014 (Fang et al., 2014). Instrumen yang digunakan untuk mengukur variabel trust mengadopsi dari instrumen Hong \& Cho (2011) yang melakukan penelitian di tahun 2011. Instrumen yang digunakan untuk mengukur variabel PEES mengadopsi instrumen yang dibuat dan digunakan oleh Pavlou dan Gefen yang melakukan penelitian di tahun 2004 (Pavlou \& Gefen, 2004). Instrumen yang digunakan dimodifikasi dan disesuaikan dengan background responden. Pilot test dilakukan terhadap instrumen tersebut untuk mendapatkan masukan dan juga pendapat mengenai instrumen yang telah diterjemahkan.

Analisis data yang digunakan untuk menjawab hipotesis dalam penelitian ini adalah menggunakan Moderated Regression Analysis (MRA). Moderated Regression Analysis dapat digunakan untuk melakukan analisis dengan variabel moderasi (Ghozali, 2018). MRA dapat dilakukan dengan cara regresi menggunakan variabel interaksi (Ghozali, 2018). Sebelum melakukan regresi, data terlebih dahulu diuji dengan menggunakan uji asumsi normalitas, uji heteroskedastisitas, dan juga uji multikolinearitas.

\section{Hasil dan Pembahasan}

Kuisioner pada penelitian ini didistribusikan melalui bantuan Google Form. Penggunaan Google Form dimaksudkan untuk mempermudah menjangkau responden yang sesuai dengan kriteria penelitian. Responden dalam penelitian ini merupakan masyarakat di Indonesia yang pernah melakukan transaksi di $e$-commerce dalam kurun waktu enam bulan terakhir. Teknik pengambilan sampel yang digunakan adalah non-probability sampling dengan sampel sebanyak 79 responden yang diambil menggunakan rumus (Tabachnick \& Fidell, 2018):

$$
N>50+8 m
$$

dimana:

$N$ : Jumlah sample;

$m$ : Jumlah variable.

Bila dihitung dengan rumus tersebut didapatkan $\mathrm{N}=50+8(3)$ yaitu 74 . Berdasarkan data yang dapat diolah, responden pernah melakukan transaksi di berbagai macam e-commerce. Pemetaan transaksi para responden di $e$-commerce dapat dilihat pada tabel 1 dan juga gambar 2. Berdasarkan hasil pengolahan data responden di tabel 1 dan gambar 2, responden paling banyak melakukan transaksi di e-commerce Shopee, diikuti dengan Tokopedia, Bukalapak, dan e-commerce lainnya.

Pengujian validitas dan reliabilitas penting untuk dilakukan. Pengujian va- 
Tabel 1: Pemetaan Transaksi Responden di E-commerce

\begin{tabular}{lc}
\hline \hline E-Commerce & Persentase Transaksi \\
\hline Shopee & $43 \%$ \\
Tokopedia & $30 \%$ \\
Bukalapak & $16 \%$ \\
Lainnya & $11 \%$ \\
\hline Sumber: Hasil olah data $(2020)$
\end{tabular}

liditas dalam penelitian ini menggunakan korelasi bivariate. Suatu instrumen dapat dinyatakan valid ketika masing-masing item berkorelasi signifikan terhadap total skor konstruknya (Ghozali, 2018). Hasil pengujian validitas yang dilakukan menunjukkan bahwa seluruh item dalam instrumen yang digunakan adalah valid, karena masing-masing item dalam instrumen berkorelasi signifikan terhadap total skor konstruk.

Pengujian reliabilitas penting untuk dilakukan sebelum melakukan analisis data. Reliabilitas instrumen dapat diuji menggunakan Uji Cronbach Alpha (Ghozali, 2018). Instrumen dapat dinyatakan reliable ketika hasil pengujiannya menunjukkan nilai Cronbach Alpha lebih dari 0,7 (Ghozali, 2018). Hasil pengujian dari data yang didapat menunjukkan bahwa seluruh nilai Cronbach Alpha di atas 0,7 sehingga dapat dikatakan bahwa instrumen yang digunakan reliable.

Pengujian normalitas digunakan untuk mengetahui distribusi variabel yang akan diuji (Ghozali, 2018). Pengujian normalitas residual dalam penelitian ini menggunakan One-Sample Kolmogorov-Smirnov Test. Hasil pengujian normalitas dalam penelitian ini menunjukkan bahwa residual tidak terdistribusi normal. Meskipun demikian, hal tersebut tidak terlalu mempengaruhi hasil pengujian analisis data yang akan dilakukan. Pada Central Limit Theorem, ketika jumlah sampel yang digunakan sudah cukup besar, maka slope dan juga intersepnya akan mendekati distribusi normal (Rice, 2007). Merujuk pada Central Limit Theorem, dapat dikatakan bahwa ketika slope dan intersep dari data sudah mendekati normal, pengujian analisis data yang dilakukan akan tetap valid (Rice, 2007).

Pengujian heteroskedastisitas dalam penelitian ini menggunakan Uji Glejser. Hasil pengujian heteroskedastisitas menunjukkan bahwa tidak ada variabel yang signifikan terhadap variabel dependen absolut residual. Hasil pengujian variabel independen tidak signifikan terhadap variabel dependen absolut residual menunjukkan bahwa tidak terjadi heteroskedastisitas (Ghozali, 2018).

Pengujian multikolinearitas pada penelitian ini menggunakan uji VIF. Nilai VIF yang kurang dari 10 menunjukkan bahwa tidak terjadi multikolinearitas pada variabel independen (Ghozali, 2018). Hasil pengujian VIF pada penelitian ini menunjukkan nilai lebih dari sepuluh untuk semua variabel. Hal tersebut menunjukkan bahwa terjadi multikolinearitas pada variabel independen. Namun, hal tersebut seringkali terjadi pada pengujian yang memuat variabel interaktif (Ghozali, 2018). Pengujian dalam penelitian ini melibatkan variabel interaktif karena akan menguji hubungan moderasi. Nilai VIF yang tinggi pada pengujian dengan variabel interaktif tidak menjadi halangan untuk melakukan pengujian 
MRA dan hasil pengujian tersebut akan tetap valid (Hartono, 2018).

Pengujian Moderated Regression Analysis dilakukan dengan bantuan SPSS. Pengujian MRA dilakukan dengan persamaan, yaitu:

$$
\text { TrustSeller }=\alpha+\beta 1 \text { Satisfaction }+\beta 2 \text { Escrow }+\beta 3 \text { Satiss } x \text { Escrow }+e
$$

Hipotesis 1 dan 2 dapat terjawab dengan melakukan regresi persamaan (1). Nilai yang dihasilkan dari pengujian penelitian ini dapat dilihat pada Tabel 2, yaitu tabel hasil uji regresi persamaan (1). Hasil pengujian menunjukkan bahwa variabel kepuasan berpengaruh terhadap variabel variabel kepercayaan. Hal tersebut ditunjukkan dengan nilai signifikansi sebesar 0,001 dalam hasil pengujian. Variabel interaksi kepuasan dan PEES memiliki nilai $p$-value atau signifikansi 0,014 , dengan nilai t -2,518 dan nilai B -3,39. Hasil pengujian menunjukkan bahwa variabel PEES sebagai variabel independen juga berpengaruh secara signifikan terhadap variabel kepercayaan.

Tabel 2: Hasil Uji Regresi Persamaan (1)

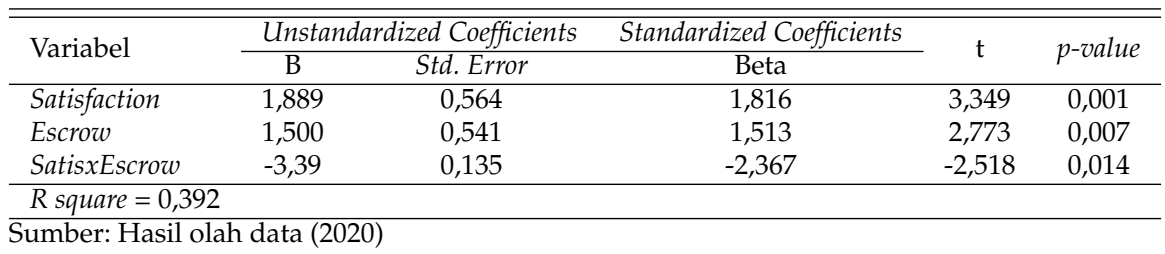

Hasil pengujian menunjukkan bahwa hipotesis 1 terdukung. Berdasarkan hasil pengujian tersebut, dapat dikatakan bahwa kepuasan yang dirasakan oleh para responden terhadap pembelian sebelumnya dapat mempengaruhi kepercayaan responden (konsumen) kepada para penjual di e-commerce. Hasil pengujian dalam penelitian ini sejalan dengan penelitian sebelumnya bahwa rasa puas yang dirasakan konsumen akan menciptakan kepercayaan konsumen pada pembelian berikutnya dalam lingkup transaksi daring yang dilakukan di $e$-commerce (Fang et al., 2014).

Hipotesis 2 dalam penelitian ini terdukung secara statistik berdasarkan hasil pengujian yang dilakukan. Hal tersebut dapat dikatakan bahwa variabel PEES mampu memoderasi hubungan antara variabel kepuasan dan kepercayaan, namun variabel PEES bukan menjadi variabel pure moderator, melainkan menjadi variabel quasi-moderator. Ketika variabel moderator berpengaruh terhadap variabel dependen, namun variabel interaksinya juga secara signifikan memoderasi hubungan antara variabel independen dan dependen, maka variabel tersebut berperan sebagai variabel kuasi moderator (Ghozali, 2018).

Hasil pengujian pada penelitian ini sejalan dengan penelitian sebelumnya bahwa PEES memoderasi hubungan antara satisfaction dan juga trust atau kepercayaan pelanggan (Fang et al., 2014). Ada hal menarik yang dapat dilihat dari hasil pengujian ini. Beta atau koefisien dari variabel interaksi bernilai negatif, 
dapat dikatakan bahwa peran moderasi dalam hubungan satisfaction dan trust adalah negatif. Pada situasi yang penuh dengan ketidakpastian, konsumen akan cenderung untuk mencari informasi lain dan kurang bergantung pada pengalaman transaksi sebelumnya, sehingga konsumen juga akan kurang bergantung pada kepuasan yang dirasakan dari transaksi sebelumnya (Fang et al., 2014). Hasil penelitian ini menunjukkan hal sebaliknya, yaitu ketika PEES tinggi maka hubungan satisfaction dan trust justru akan melemah, dan pada saat PEES rendah maka hubungan satisfaction dan trust akan meningkat. Dapat diartikan bahwa ketika penyedia jasa e-commerce telah menggunakan PEES, maka konsumen akan mengesampingkan satisfaction dan trust pada e-commerce tersebut. Masyarakat akan memilih bertransaksi pada e-commerce yang telah menggunakan PEES sekalipun mereka belum pernah melakukan transaksi pada $e$-commerce tersebut. Sebaliknya, apabila PEES belum diterapkan oleh penyedia jasa e-commerce, maka konsumen akan memilih marketplace yang memberikan satisfaction dan trust pada transaksi sebelumnya.

\section{Kesimpulan}

Berdasarkan hasil penelitian yang dilakukan dapat dikatakan bahwa kepuasan yang dirasakan oleh responden terhadap pembelian sebelumnya dapat mempengaruhi kepercayaan konsumen terhadap penjual. Dapat dikatakan bahwa variabel PEES mampu memoderasi hubungan antara variabel kepuasan dan kepercayaan. Hasil pengujian dalam penelitian ini sejalan dengan penelitian sebelumnya bahwa rasa puas yang dirasakan konsumen akan menciptakan kepercayaan konsumen pada pembelian berikutnya dalam lingkup transaksi daring yang dilakukan di e-commerce (Fang et al., 2014). Variabel PEES mampu memoderasi hubungan antara variabel kepuasan dan kepercayaan, namun variabel PEES bukan menjadi variabel pure moderator, melainkan menjadi variabel kuasi moderator. Hasil pengujian pada penelitian ini sejalan dengan penelitian sebelumnya bahwa PEES memoderasi hubungan antara satisfaction dan juga trust atau kepercayaan pelanggan (Fang et al., 2014). Melalui penelitian ini para pengelola e-commerce dapat menerapkan jasa escrow pada marketplace yang dikelolanya karena dengan adanya jasa escrow, maka pembeli yang belum pernah melakukan pembelian sebelumnya bisa lebih percaya terhadap e-commerce tersebut dan berdampak meningkatkan angka pembelian.

\subsection{Saran}

Keterbatasan dalam penelitian ini adalah bahwa tim peneliti tidak mengukur seberapa besar kepuasan yang dirasakan oleh responden pada pembelian sebelumnya. Adanya tingkat kepuasan yang berbeda-beda pada tiap responden mungkin dapat mempengaruhi tingkat kepercayaan yang dirasakan para responden. Kuesioner penelitian ini tidak mengukur tingkat persepsi risiko yang dirasakan para responden ketika melakukan transaksi di e-commerce. Pada situ- 
asi yang terdapat ketidakpastian dan juga risiko, konsumen cenderung untuk mencari informasi lain sebelum melakukan pembelian, dan tidak bergantung pada kepuasan yang telah dirasakan sebelumnya (Fang et al., 2014). Tingkat risiko yang berbeda pada tiap responden dapat memengaruhi kepercayaan dan juga kepuasan responden dari pembelian sebelumnya. Penelitian ini juga tidak memetakan lokasi responden berada. Kuesioner yang dibagikan tidak terdapat opsi pengisian lokasi responden. Penelitian selanjutnya dapat menambahkan pemetaan lokasi responden. Penelitian ini tidak mengakomodir responden yang melakukan pembelian online pada lebih dari satu e-commerce, oleh karena itu peneliti berikutnya dapat menambahkan opsi pada kuesioner berupa pemilihan lebih dari satu e-commerce.

Penelitian selanjutnya dapat melakukan penelitian serupa dengan eksplorasi yang lebih mendalam mengenai peran moderasi negatif variabel PEES terhadap hubungan satisfaction dan trust. Penelitian selanjutnya juga dapat mengeksplorasi lebih dalam lagi mengenai pengaruh tingkat kepuasan dan juga tingkat persepsi risiko yang dirasakan oleh konsumen terhadap kepuasan, kepercayaan, dan PEES.

\section{Daftar Pustaka}

[1] Akbar, M. S., \& Azeemi, N. Z. (2017). Factors affecting consumers' behavior towards E-Shop in KSA. Strategic Management Quarterly, 5(3 \& 4), 9-16. doi: $0.15640 /$ smq.v5n3_4a2.

[2] Anderson, R. E., \& Srinivasan, S. S. (2003). E-satisfaction and e-loyalty: A contingency framework. Psychology \& Marketing, 20(2), 123-138. doi: https://doi.org/10.1002/mar.10063.

[3] Azam, A., Qiang, P. F., \& Abdullah, M. I. (2012). Consumers' E-commerce acceptance model: Antecedents of trust and satisfaction constructs. In 2012 IEEE Business, Engineering $\mathcal{E}$ Industrial Applications Colloquium (BEIAC) (pp. 371-376), Kuala Lumpur, Malaysia. Institute of Electrical and Electronics Engineers (IEEE). doi: https://doi.org/10.1109/BEIAC.2012.6226086.

[4] Byambaa, B., \& Chang, K. (2012). The influence of factors of online purchase on customer satisfaction in Mongolian Airlines. International Proceedings of Economics Development and Research, 57, 80-85.

[5] Eid, M. I. (2011). Determinants of e-commerce customer satisfaction, trust, and loyalty in Saudi Arabia. Journal of Electronic Commerce Research, 12(1), 78-93.

[6] Elbeltagi, I., \& Agag, G. (2016). E-retailing ethics and its impact on customer satisfaction and repurchase intention. Internet Research, 26(1), 288-310. doi: https:/ / doi.org/10.1108/IntR-10-2014-0244.

[7] Fang, Y., Qureshi, I., Sun, H., McCole, P., Ramsey, E., \& Lim, K. H. (2014). Trust, satisfaction, and online repurchase intention: The moderating role of perceived effectiveness of e-commerce institutional mechanisms. MIS Quarterly, 38(2), 407-A9. doi: $10.2307 / 26634932$.

[8] Ghane, S. O. H. E. I. L. A., Fathian, M., \& Gholamian, M. R. (2011). Full relationship among e-satisfaction, e-trust, e-service quality, and e-loyalty: The case of Iran ebanking. Journal of Theoretical and Applied Information Technology, 33(1), 1-6. 
[9] Ghozali, I. (2018). Aplikasi analisis multivariate dengan program IBM SPSS 25 (Edisi 9). Badan Penerbit Universitas Diponegoro.

[10] Hartono, J. (2018). Metodologi penelitian bisnis: salah kaprah dan pengalaman-pengalaman. BPFE.

[11] Hong, I. B., \& Cho, H. (2011). The impact of consumer trust on attitudinal loyalty and purchase intentions in B2C e-marketplaces: Intermediary trust vs. seller trust. International Journal of Information Management, 31(5), 469-479. doi: https://doi.org/10.1016/j.ijinfomgt.2011.02.001.

[12] Hu, X., Lin, Z., Whinston, A. B., \& Zhang, H. (2004). Hope or hype: On the viability of escrow services as trusted third parties in online auction environments. Information Systems Research, 15(3), 215-310. doi: https://doi.org/10.1287/isre.1040.0027.

[13] iPrice. (2019). Peta e-Commerce Indonesia. https://iprice.co.id/insights/ mapofecommerce/.

[14] Jones, K., \& Leonard, L. N. (2008). Trust in consumer-to-consumer electronic commerce. Information $\mathcal{E}$ Management, 45(2), 88-95. doi: https://doi.org/10.1016/j.im.2007.12.002.

[15] Kassim, N., \& Abdullah, N. A. (2010). The effect of perceived service quality dimensions on customer satisfaction, trust, and loyalty in e-commerce settings. Asia Pacific Journal of Marketing and Logistics, 22(3), 351-371. doi: https://doi.org/10.1108/13555851011062269.

[16] Kaura, V., Prasad, C. S. D., \& Sharma, S. (2015). Service quality, service convenience, price and fairness, customer loyalty, and the mediating role of customer satisfaction. International Journal of Bank Marketing, 33(4), 404-422. doi: https://doi.org/10.1108/IJBM-04-2014-0048.

[17] Kemp, S. (2020). Digital 2020: Indonesia. Data Reportal. https://datareportal.com/ reports/digital-2020-indonesia.

[18] Kim, D. J., Ferrin, D. L., \& Rao, H. R. (2009). Trust and satisfaction, two stepping stones for successful e-commerce relationships: A longitudinal exploration. Information Systems Research, 20(2), 159-316. doi: https://doi.org/10.1287/isre.1080.0188.

[19] Lee, W. O., \& Wong, L. S. (2016). Determinants of mobile commerce customer loyalty in Malaysia. Procedia-Social and Behavioral Sciences, 224, 60-67. doi: https://doi.org/10.1016/j.sbspro.2016.05.400.

[20] Mayer, R. C., Davis, J. H., \& Schoorman, F. D. (1995). An integrative model of organizational trust. Academy of Management Review, 20(3), 709-734. doi: https://doi.org/10.5465/amr.1995.9508080335.

[21] Mou, J., Cohen, J., Dou, Y., \& Zhang, B. (2017). Predicting buyers'repurchase intentions in cross-border e-commerce: A valence framework perspective. In Proceedings of the 25th European Conference on Information Systems (ECIS) (pp. 2382-2394), Guimarães, Portugal, June 5-10, 2017.

[22] Nah, F. F. H., \& Davis, S. (2002). HCI research issues in e-commerce. Journal of Electronic Commerce Research, 3(3), 98-113.

[23] Nisar, T. M., \& Prabhakar, G. (2017). What factors determine e-satisfaction and consumer spending in e-commerce retailing?. Journal of Retailing and Consumer Services, 39, 135-144. doi: https://doi.org/10.1016/j.jretconser.2017.07.010.

[24] Oliveira, T., Alhinho, M., Rita, P., \& Dhillon, G. (2017). Modelling and testing consumer trust dimensions in e-commerce. Computers in Human Behavior, 71, 153-164. doi: https://doi.org/10.1016/j.chb.2017.01.050.

[25] Palvia, P. (2009). The role of trust in e-commerce relational exchange: 
A unified model. Information $\mathcal{E}$ Management, 46(4), 213-220. doi: https://doi.org/10.1016/j.im.2009.02.003.

[26] Pappas, I. O., Pateli, A. G., Giannakos, M. N., \& Chrissikopoulos, V. (2014). Moderating effects of online shopping experience on customer satisfaction and repurchase intentions. International Journal of Retail E Distribution Management, 42(3), 187-204. doi: https://doi.org/10.1108/IJRDM-03-2012-0034.

[27] Pavlou, P. A., \& Gefen, D. (2004). Building effective online marketplaces with institution-based trust. Information Systems Research, 15(1), 37-59. doi: https://doi.org/10.1287/isre.1040.0015.

[28] Pavlou, P. A., Liang, H., \& Xue, Y. (2007). Understanding and mitigating uncertainty in online exchange relationships: A principal-agent perspective. MIS Quarterly, 31(1), 105-136. doi: https://doi.org/10.2307/25148783.

[29] Rahayu, N. (2019). Pertumbuhan e-commerce pesat di Indonesia. Warta Ekonomi online. https://www.wartaekonomi.co.id/read216302/ pertumbuhan-e-commerce-pesat-di-indonesia.

[30] Rice, J. A. (2007). Mathematical statistics and data analysis. Thomson/Brooks/Cole.

[31] Rust, R. T., \& Zahorik, A. J. (1993). Customer satisfaction, customer retention, and market share. Journal of Retailing, 69(2), 193-215. doi: https://doi.org/10.1016/00224359(93)90003-2.

[32] Sharma, G., \& Lijuan, W. (2015). The effects of online service quality of ecommerce Websites on user satisfaction. The Electronic Library, 33(3), 468-485. doi: https://doi.org/10.1108/EL-10-2013-0193.

[33] Sullivan, Y. W., \& Kim, D. J. (2018). Assessing the effects of consumers' product evaluations and trust on repurchase intention in e-commerce environments. International Journal of Information Management, 39, 199-219. doi: https://doi.org/10.1016/j.ijinfomgt.2017.12.008.

[34] SWA.co.id. (2016). Jamin transaksi 100\% aman, Bukalapak dorong kemajuan UKM. https://swa.co.id/beritabca/bca/ jamin-transaksi-100-aman-bukalapak-dorong-kemajuan-ukm.

[35] Tabachnick, B. G., \& Fidell, L. S. (2018). Using multivariate statistics (7th Edition). Pearson.

[36] Tempo.co (2017, 1 Desember). E-Commerce dongkrak pertumbuhan industri logistik 30 persen. https://bisnis.tempo.co/read/1038571/ e-commerce-dongkrak-pertumbuhan-industri-logistik-30-persen/full\&view=ok.

[37] Ting, O. S., Ariff, M. S. M., Zakuan, N., Sulaiman, Z., \& Saman, M. Z. M. (2016). E-service quality, e-satisfaction and e-loyalty of online shoppers in business to consumer market; Evidence form Malaysia. In IOP Conference Series: Materials Science and Engineering (Vol. 131, No. 1, p. 012012). IOP Publishing.

[38] Xu, H., Liu, D., Wang, H., \& Stavrou, A. (2015). E-commerce reputation manipulation: The emergence of reputation-escalation-as-a-service. In Proceedings of the 24th International Conference on World Wide Web (pp. 1296-1306). doi: https://doi.org/10.1145/2736277.2741650. 